Portland State University

PDXScholar

Center for Urban Studies Publications and Reports

Center for Urban Studies

$11-1998$

\title{
The Connection Between Public Transit and Employment
}

Thomas W. Sanchez

Portland State University

Follow this and additional works at: https://pdxscholar.library.pdx.edu/cus_pubs

Part of the Transportation Commons, and the Urban Studies and Planning Commons Let us know how access to this document benefits you.

\section{Citation Details}

Sanchez, Thomas W., "The Connection Between Public Transit and Employment" (1998). Center for Urban Studies Publications and Reports. 23.

https://pdxscholar.library.pdx.edu/cus_pubs/23

This Working Paper is brought to you for free and open access. It has been accepted for inclusion in Center for Urban Studies Publications and Reports by an authorized administrator of PDXScholar. Please contact us if we can make this document more accessible: pdxscholar@pdx.edu. 
The Connection Between Public Transit and Employment

by

\author{
Thomas W. Sanchez, Assistant Professor
}

Center for Urban Studies

School of Urban Studies and Planning

Portland State University

PO Box 751-CUS

Portland, OR 97207-0751

DP98-7

Phone: 503-725-8743

Fax: 503-725-8480

E-mail: sanchezt@pdx.edu

http://www.upa.pdx.edu/CUS/PROFILES/TWS/

Prepared for Presentation at the Association of Collegiate Schools of Planning Annual Conference

Pasadena, CA

4-7 November 1998 


\title{
The Connection between Public Transit and Employment
}

\begin{abstract}
Even with a considerable amount of attention being paid to the role of public transportation in addressing inner-city mobility problems, there is very little evidence of the degree to which one affects the other. In other words, little research has specifically focused on how labor participation is impacted by increases in public transportation availability. Research on the spatial mismatch hypothesis has dealt with the relationship between labor participation and the spatial separation of jobs and houses; however, most analyses concentrate on commuting time or distance as a function of auto accessibility. Few, if any, studies have considered the relative impacts of employment accessibility that results from public transportation services. This study uses a geographic information system (GIS) to analyze the location and employment characteristics of workers with varying levels of accessibility to transit. Utilizing a variety of spatial measures, a two-stage least squares regression is used to estimate the relationship of transit accessibility with labor participation levels for the cities of Portland, Oregon and Atlanta, Georgia. The results suggest that transit access is a significant factor in determining average rates of labor participation within these two cities.
\end{abstract}




\title{
The Connection between Public Transit and Employment
}

\begin{abstract}
When you go beyond a relatively simple though serious problem such as police racism, however, you begin to get all the complexities of the modern American economy. Urban transit systems in most American cities, for example, have become a genuine civil rights issue -- and a valid one -- because the layout of rapid-transit systems determines the accessibility of jobs to the black community. If transportation systems in American cities could be laid out so as to provide an opportunity for poor people to get meaningful employment, then they could begin to move into the mainstream of American life. A good example of this problem is my home city of Atlanta, where the rapid-transit system has been laid out for the convenience of the white upper-middle-class suburbanites who commute to their jobs downtown. The system has virtually no consideration for connecting the poor people with their jobs. There is only one possible explanation for this situation, and that is the racist blindness of city planners.
\end{abstract}

Martin Luther King, Jr., A Testament of Hope, essay published posthumously, January, 1969)

\section{$\underline{\text { Introduction }}$}

The remarks of Martin Luther King, Jr. regarding the failure of transit services to overcome disparities in job accessibility among racial groups highlight an on-going debate among urban analysts. Out of the Los Angeles civil rights protests of the 1960s, the McCone Commission identified inadequate transportation as contributing to high rates of unemployment among the black urban population (Kain and Meyer 1970). In 1968, the National Advisory Commission on Civil Disorders (NACCD, also known as the Kerner Commission) released its report on the causes and effects of riots in U.S. cities. Among their recommendations for enhanced employment opportunities for central city residents was the creation of improved transportation links between ghetto neighborhoods and new job locations in the suburbs (NACCD 1968). Years later, the Intermodal Surface Transportation Efficiency Act (ISTEA) of 1991 promised to improve the mobility of the economically disadvantaged through "intermodal connections between people and jobs, goods and markets, and neighborhoods" (Bullard 1996). More recently, the Personal Responsibility and Work Opportunity Act of 1996 (PROWA), "welfare-to-work", and job access programs have been initiated to address low-income mobility problems (Willis 1997; US DOT 1998). In addition to concerns about unequal job access, other related issues have also arisen over the fairness of transit service pricing as well as the quality of service provision (Hodge 1995; Hernandez 1996; Bullard and Johnson 1997).

Even with a considerable amount of attention being paid to the role of public transportation in addressing inner-city mobility problems, there is very little evidence of the degree to which one affects the other. In other words, very few urban researchers have specifically focused on how labor participation is affected by increases in public transportation availability. A significant amount of research has dealt with the relationship between labor force participation and the spatial separation of jobs and houses; however, most analyses concentrate on commuting time or distance as a function of auto accessibility. Few studies have considered the relative impacts of employment accessibility that result from public transportation services, while continuing to recommend public transportation expenditures to address unemployment problems (e.g., NACCD 1968; Blackley 1990; Hughes 1991). The emphasis of contemporary research is on the measurement of commuting costs, which can only consider persons who have a job (and a car) -- while the unemployed (or immobile) are ignored. Unemployment levels are indirectly accounted for in analyses of transit impacts on income distribution (Frankena 1973; Dajani and Egan 1974), but these do not address the significant difference between neighborhoods with employed persons in poverty and neighborhoods with nonemployed persons in poverty (Wilson 1997). 
If labor participation for different racial groups is affected by poor employment accessibility and poor worker mobility, and, if public transportation services are designed to effectively link workers with employment concentrations, it stands to reason that transit accessibility should yield employment benefits (Sanchez 1998). The objective of this paper is to examine whether transit is effectively linking the residential location of workers with job locations in Portland, Oregon and Atlanta, Georgia. This is done by comparing labor participation rates for workers within walking distance of transit routes to labor participation rates of workers not within walking distance. The analysis controls for race, job skill levels, relative employment accessibility, and household characteristics as primary factors affecting employment for central city workers. This research addresses associated issues that comprise the "spatial mismatch hypothesis" and includes a discussion of prior spatial mismatch research efforts to provide background in the areas of job location, residential location, central city employment, and public transportation.

A major factor underlying the spatial mismatch hypothesis (SMH) is the deconcentration of jobs from U.S. central cities. Despite the trend of businesses to relocate outward, a large proportion of metropolitan employment remains in downtowns. The argument is not simply that central cities are devoid of employment opportunities, rather, the educational background and skills of central city residents are not suited for the jobs that they live near (Kasarda 1983, Wachs and Taylor 1998). Managerial and information processing services have tended to remain in downtown districts while entry level, low-skill jobs are flowing to the urban fringe and beyond. Evidence suggests that the average distance between a central city resident's home and potential employment locations has been increasing over time (Holzer 1991). As this distance increases, low-skill workers with low levels of personal mobility are not able to meet the travel requirements of these new, dispersed locations. In fact, low-income households are over six times less likely to own a vehicle than middle or upper income households (Murakami and Young 1997). When jobs that residents are qualified to perform are concentrated, commute times and distances are shorter than when these jobs are more dispersed. An equally inefficient pattern of commuting can occur with long intra-city commuting, where residential location is not a direct function of minimized work commute decision-making (Cohn and Fossett 1996). On the other hand, others have argued that travel economies result as residences and jobs disperse (Gordon, Kumar, and Richardson 1989, Levinson and Kumar 1994). Such findings further the debate about the impacts of urban spatial dynamics on employment levels.

Urban transit systems operate efficiently in concentrated, densely developed urban areas. These systems, which also tend to be oriented to the downtown, do a poor job of serving dispersed trip origins and destinations (Kain 1968). In addition, modal preferences are so strongly in favor of automobiles that mobility benefits from transit have been considered negligible (Kain and Meyer 1970; Gómez-Ibáñez 1976; Meyer and Gómez-Ibáñez 1981; Holzer, Ihlanfeldt, and Sjoquist 1994; Taylor and Ong 1995).

\section{Previous spatial mismatch research}

Research efforts on SMH have produced mixed results both supporting and rejecting the hypothesis. These differing results may be a function of the different methods, data, and assumptions that have been employed to analyze the problem. Some of these studies rely upon aggregate data to analyze the mismatch between employment and residential locations (Kain 1992). Others have analyzed zonal data (census tracts, traffic analysis zones, etc.) and while still aggregate in nature, these data provide neighborhood levels of comparison for disparities in employment accessibility and labor participation rates (Ellwood 1986; Hughes 1991; Ihlanfeldt 1994; Wyly 1996; Cohn and Fossett 1996). Disaggregate (household) data has also been used effectively to compare worker characteristics (educational levels, occupation, income level), mobility (car ownership levels) and commuting patterns (time and distance), and employment indicators (wages and labor participation). Data sources include the American Housing Survey (Taylor and Ong 1995), Nationwide Personal Transportation Survey (Gordon, Kumar, and Richardson 1989), Census Public Use Microsamples (Ihlanfeldt and Sjoquist 1990; Holloway 1996), and other independent household surveys.

While comparing residential locations to feasible employment locations, a few important analytical issues emerge. The simple ratio of total jobs to total working age persons is an inadequate 
indicator of mismatch. Job skills, educational background, gender, race, and mobility of workers have a significant impact on the numbers and types of jobs that a worker is qualified to hold. Controlling for "skills" and "mobility" matching, the disparity in employment levels by race and gender is generally attributed to historic or contemporary discrimination (Wilson 1987). Table 1 summarizes a range of research efforts focused on the employment effects of spatial mismatch.

In terms of transit impacts, many studies have mentioned that while current patterns of urban development produce spatial mismatches, public transportation represents an inefficient means to overcome employment accessibility or mobility problems of central city workers. Some dismiss transit, compared to autos, as a viable link between central city residents and employment locations for this reason. A 1997 study in Dade County, Florida did not find a strong relationship between transit access to employment locations and employment participation (Thompson 1997). Other studies have also indirectly accounted for the role of transit in central city employment levels by incorporating transit travel times into job accessibility calculations (Ellwood 1986). Still other studies have simply ignored public transportation as a meaningful work trip mode and excluded it from employment accessibility estimates (Gordon, Kumar, and Richardson 1989).

Table 1 Employment effects of spatial mismatch (adapted from Holzer 1991)

\begin{tabular}{|c|c|c|}
\hline Author & Year & Findings \\
\hline Kain & 1968 & $\begin{array}{l}\text { Housing segregation contributes to high unemployment rates of metropolitan } \\
\text { blacks }\end{array}$ \\
\hline Mooney & 1969 & Black unemployment rises with job decentralization \\
\hline Offner and Saks & 1971 & $\begin{array}{l}\text { Using Kain's data, they refute the degree of impact of desegregation on black } \\
\text { unemployment levels }\end{array}$ \\
\hline Friedlander & 1972 & Segregation indices have few significant effects on central city black employment \\
\hline Harrison & 1974 & $\begin{array}{l}\text { Labor participation (weeks worked) not significantly different for urban and } \\
\text { suburban blacks }\end{array}$ \\
\hline Hutchinson & 1974 & $\begin{array}{l}\text { Proximity to employment concentrations negatively correlated with black } \\
\text { employment }\end{array}$ \\
\hline Kasarda & 1983 & $\begin{array}{l}\text { Industrial transportation of metropolitan economies are producing high rates of } \\
\text { unemployment }\end{array}$ \\
\hline Leonard & 1985 & Measures of job access not significantly related to black and teen employment \\
\hline Ellwood & 1986 & Measures of job access not significantly related to black and youth employment \\
\hline Farley & 1987 & Job decentralization raises relative unemployment rates among blacks and hispanics \\
\hline Ihlanfeldt and Sjoquist & 1989 & Average travel times have large effects on employment levels of black youth \\
\hline Blackley & 1990 & Spatial mismatch hypothesis is supported for females in large metropolitan areas \\
\hline Ihlanfeldt and Sjoquist & 1990 & Average travel times have large effects on employment levels of black youth \\
\hline Ihlanfeldt & 1993 & $\begin{array}{l}\text { Poor job accessibility contributes to labor market problems of inner city minority } \\
\text { workers }\end{array}$ \\
\hline Taylor and Ong & 1995 & $\begin{array}{l}\text { Spatial mismatch hypothesis not supported by commuting differences between } \\
\text { racial groups }\end{array}$ \\
\hline
\end{tabular}

Based on results from spatial mismatch analyses, a primary research question emerges: does public transportation significantly affect unemployment levels in urban areas? Despite the lack of evidence, public transportation enhancements continue to be recommended as viable strategies in combating central city unemployment problems (Blackley 1990, Hughes 1991, Willis 1997).

\section{Methodology}

To examine the impact transit has on connecting urban residents with job locations, labor participation rates (average annual weeks worked as reported by the 1990 U.S. Census) for residents living within walking distances of transit routes are compared to labor participation rates for residents 
not living within walking distances in the cities of Portland and Atlanta. Controlling for job skill levels, race, and other household characteristics, it is hypothesized that labor participation should be at least marginally higher for workers having good access to transit than for those who do not. In terms of job accessibility, it is common for workers with high transit use to have longer average commute times compared to other workers, simply because travel by transit has higher time costs than does personal auto travel (Downs 1992). For this reason, travel time alone is considered to be an unreliable measure of relative employment accessibility.

This study uses a geographic information system (GIS) to analyze the location and employment characteristics of residents with varying levels of accessibility to transit. Accessibility to transit is typically considered to be good if persons are within walking distance to a stop and from a transit stop to their destination. Walking distances of $0.40 \mathrm{~km}(0.25$ miles $)$ are usually considered the maximum distance that people are willing to walk to use public transportation (UMTA 1979). Using block group census data and transit route locations within the GIS, block groups within $0.40 \mathrm{~km}$ of the nearest transit route (or stop) were selected for analysis. The STF3A census data reports commuting characteristics such as travel time and time leaving for work; labor participation rates by race and gender; household characteristics such as vehicle ownership and income; and occupational information. The 1990 Census Transportation Planning Package (CTPP) provided the employment location information at the traffic analysis zone (TAZ) level.

A potential problem with the analysis is that block groups are irregularly shaped and increase in size with increasing distance from downtowns. This means that a $0.40 \mathrm{~km}$ buffer around transit routes will not correspond with block group boundaries. The selection of block groups can be performed in a variety of ways; using the centroid method, a percent-inside method, or a touching method. Each method represents a different criteria for spatial queries. A solution to this problem would be to use census block data instead of block groups, however, considerably less household data is reported for census blocks compared to block groups. In addition, urban household characteristics vary from neighborhood to neighborhood as well as city block to city block. If block group data are disaggregated to the block level through an allocation procedure, it is likely that the spatial variation of the household characteristics will be improperly represented. One of the primary purposes of this analysis is to consider the impacts of transit route location on household ridership and employment levels proximate to routes. Estimations of household types from aggregate data may dilute or underrepresent the spatial variation of households by race, gender, income, and employment status. A sensitivity analysis could be used to detect if there are significant differences in the results if different methods of spatial coincidence are used (e.g., centroid method, percent-inside, and touching).

\section{$\underline{\text { Study areas }}$}

The study areas for this research are the cities of Portland and Atlanta. While Portland and Atlanta are similar in respect to relative population size, economic vitality, and transit service availability, they are good case study examples because they also contrast. The 1990 population of Portland and Atlanta were 437,000 and 394,000 respectively. The metropolitan statistical areas (MSAs) associated with each city had three to seven times the total population of the central city with the MSAs for Portland and Atlanta having 1,478,000 and 2,834,000 persons respectively. Portland's population grew by 18.8 percent (mostly through annexations) between 1980 and 1990 while Atlanta's declined by 7.3 percent. For this same period the Atlanta MSA population increased by 32.5 percent while Portland's grew by 13.9 percent - indicating the difference in degree of suburbanization between the two cities. The two cities also differ significantly in terms of racial composition. In 1990 Atlanta was second only to Gary, Indiana in the proportion of black residents (Atlanta with 67.1 percent and Gary with 80.6 percent). On the other hand, the total number of nonwhite residents represented only 17.4 percent of Portland's population in 1990. Similar to nearly all other urban areas in the U.S., there are geographic concentrations of low-income households and nonwhite households within two cities. As can be seen in Figures 1 and 2, both Portland and Atlanta have public bus and rail transit service exhibiting extensive geographic coverage within their city limits. In both cities, 77 to 86 percent of workers have good access to transit (see Table 2). 
Using Portland and Atlanta as case study cities provides what could be "best case" scenarios for transit related studies. Both cities provide high levels of transit service. In addition, Portland's land use and transit planning is recognized as being the most progressive within the U.S. and Atlanta is among the leading cities in modal share accommodated by transit. For those reasons, the results of this analysis could be seen as the high range of what urban areas could hope to achieve in linking workers with jobs using transit. Further research that examines a broader range of city types with varying levels of transit service could provide important evidence about the role of transit. Comparing cities of similar size and composition and significantly different transit systems could indicate the marginal benefits of increased levels of transit services in affecting employment attachment. Such research results could provide cities with reasonable expectations about the employment benefits of increases in transit accessibility and levels of service.

\section{Analysis of employment and transit system accessibility}

Table 2 compares the employment characteristics of workers for block groups that are within walking distance of either a bus route or rail station and city averages for Portland and Atlanta. In general, employment levels for nonwhite workers are significantly lower than those for whites in both cities. Asian and Other residents have the highest rates of employment compared to whites. Overall, workers within walking distance of the nearest transit route are slightly more likely to be unemployed than workers on average in each city. These averages do not control for worker or household characteristics that influence employment patterns.

Table 2 Block group unemployment comparisons by race and proximity to transit for Portland, OR and Atlanta, GA: 1990

\begin{tabular}{|c|c|c|c|c|}
\hline & \multicolumn{2}{|c|}{ Portland } & \multicolumn{2}{|c|}{ Atlanta } \\
\hline & $\begin{array}{c}\text { Within } 0.40 \\
\text { km }\end{array}$ & $\begin{array}{l}\text { Entire } \\
\text { city }\end{array}$ & $\begin{array}{c}\text { Within } 0.40 \\
\text { km }\end{array}$ & $\begin{array}{l}\text { Entire } \\
\text { city }\end{array}$ \\
\hline Total workers & 306,782 & 397,437 & 164,391 & 192,033 \\
\hline Total nonwhite workers & 38,035 & 44,233 & 105,589 & 118,412 \\
\hline Percent White, unemployed & 5.25 & 4.88 & 4.07 & 3.66 \\
\hline Percent Black, unemployed & 12.56 & 12.49 & 12.98 & 12.65 \\
\hline Percent American Indian, unemployed & 12.77 & 11.80 & 16.79 & 17.23 \\
\hline Percent Asian, unemployed & 5.64 & 5.74 & 8.94 & 8.47 \\
\hline Percent Other, unemployed & 5.39 & 5.55 & 7.76 & 6.72 \\
\hline Percent total unemployment & 5.72 & 5.29 & 9.95 & 9.12 \\
\hline Percent nonwhite unemployment & 9.22 & 8.81 & 12.87 & 12.51 \\
\hline
\end{tabular}

A two-stage least squares regression method was used to predict employment levels for census block groups within Portland and Atlanta. The average number of weeks worked for workers in each block group is used as the dependent variable. In addition, to estimate the differential effects of transit accessibility on total and nonwhite employment, block group observations were grouped as being either predominantly white or predominantly nonwhite. Predominantly white block groups were those with a percentage of white residents higher than the average city block group and predominantly nonwhite block groups were those with a percentage of white residents lower than the city average. The average 1990 block group percentage of white residents for Portland and Atlanta were 87 and 32 percent respectively. In addition, only block groups within $1.61 \mathrm{~km}$ (1.0 miles) of existing transit routes are included in the regression analysis. It is assumed that workers living more than $1.61 \mathrm{~km}$ away from transit routes are unlikely to consider transit as a viable work trip mode. This resulted in 570 of 664 Portland block groups and 409 of 424 Atlanta block groups being selected. The intention is to compare workers with good transit access to those with poor access, while 
excluding workers with practically no access. Because racial groups are not uniformly distributed geographically, the counts for all nonwhite workers (Black, American Indian, Asian, and Other) were combined and classified as a single group (nonwhite). Table 3 lists the variables that are included in the regression model and Table 4 shows the descriptive statistics for the selected observations.

Table 3 Regression variables

\begin{tabular}{|c|c|c|}
\hline & Block Group Variable & $\begin{array}{l}\text { Variable } \\
\text { Name }\end{array}$ \\
\hline Dependent variables & $\begin{array}{l}\text { Average annual weeks worked for all workers } \\
\text { Average annual weeks worked for nonwhite workers }\end{array}$ & $\begin{array}{l}\text { total } \\
\text { nonwhite }\end{array}$ \\
\hline Independent variables & $\begin{array}{l}\text { Average commute time (mins) } \\
\text { Network distance to nearest rail station } \\
\text { Straight-line distance to nearest bus route } \\
\text { Transit service frequency at nearest stop } \\
\% \text { workers in executive or managerial positions } \\
\% \text { leaving for work after } 4: 00 \text { p.m. } \\
\% \text { nonwhite ages } 0 \text { to } 15 \\
\% \text { single parent households with children } \\
\% \text { white residents } \\
\text { Ratio of persons } 18+\text { with bachelors degree to workers } \\
\text { Retail job accessibility within } 25 \text { mins by transit } \\
\text { Service job accessibility within } 25 \text { mins by transit } \\
\text { Predicted average vehicles per capita (from } 1 \mathrm{st} \text { stage) }\end{array}$ & $\begin{array}{l}\text { comm_time } \\
\text { dist_rail } \\
\text { dist_bus } \\
\text { frequent } \\
\text { pexec } \\
\text { pleav_4 } \\
\text { pnw_15 } \\
\text { psingwc } \\
\text { pwhite } \\
\text { pbach } \\
\text { ret_jobs } \\
\text { ser_jobs } \\
\text { pre_veh }\end{array}$ \\
\hline
\end{tabular}

In addition to the census variables included in the model, four spatial measures estimated with the GIS control for transit and employment accessibility. The rail transit access measure is the street distance from each block group centroid to the nearest station location. The bus transit access measure is the straight-line distance to the nearest bus stop. Because bus stops are more frequent compared to rail stations, there is a very high correlation between the straight-line and network distances to bus stops. Thus, there is essentially no difference in using one measure over the other.

Along with physical access to transit stops, the level of service provided at those stops is also an important indicator of transit accessibility. Higher levels of mobility and general accessibility are achieved when frequent and reliable service is provided. To control for the level of service, the A.M. peak (7:30 a.m. to 9:30 a.m.) service frequency at the nearest stop is included in the regression equation. Peak hour service frequencies averaged between 19 and 20 minutes across routes for Portland and Atlanta. 
Table 4 Descriptive statistics for block groups in Portland, OR and Atlanta, GA: 1990

\begin{tabular}{|c|c|c|c|c|}
\hline \multirow[b]{2}{*}{ Variable1 } & \multicolumn{2}{|c|}{ Portland } & \multicolumn{2}{|c|}{ Atlanta } \\
\hline & Mean & Std Dev & Mean & Std Dev \\
\hline Average commute time (mins) & 19.80 & 4.15 & 24.90 & 7.34 \\
\hline Average weeks worked (nonwhite)2 & 41.76 & 8.22 & 40.96 & 7.23 \\
\hline Average weeks worked (total)2 & 43.96 & 5.77 & 42.48 & 6.64 \\
\hline Distance to nearest rail station $(\mathrm{km})$ & 6.07 & 6.20 & 2.86 & 2.18 \\
\hline Distance to nearest bus route $(\mathrm{km})$ & 0.24 & 0.23 & 0.19 & 0.17 \\
\hline Transit service frequency & 19.95 & 11.08 & 18.86 & 9.00 \\
\hline$\%$ workers executive or managerial & 0.12 & 0.07 & 0.10 & 0.10 \\
\hline \% leaving for work after 4:00 p.m. & 0.07 & 0.05 & 0.06 & 0.06 \\
\hline$\%$ nonwhite ages 0 to 15 & 0.04 & 0.05 & 0.16 & 0.14 \\
\hline \% single parent households w/children & 0.08 & 0.07 & 0.15 & 0.15 \\
\hline$\%$ white residents & 0.87 & 0.17 & 0.32 & 0.38 \\
\hline $\begin{array}{l}\text { Ratio of persons } 18+\text { with bachelors degrees to } \\
\text { workers }\end{array}$ & 0.23 & 0.15 & 0.20 & 0.22 \\
\hline Retail job accessibility within 25 mins 3 & 6.58 & 1.36 & 3.87 & 2.93 \\
\hline Service job accessibility within 25 mins 3 & 7.16 & 1.31 & 4.60 & 3.45 \\
\hline Predicted vehicle ownership per capita & 0.63 & 0.17 & 0.47 & 0.18 \\
\hline No. of observations & 579 & & 409 & \\
\hline
\end{tabular}

1 Only block groups within $1.61 \mathrm{~km}$ of a bus route or transit station

2 Dependent variables

3 By bus transit (natural $\log$ ) 
Figure 1 City of Portland

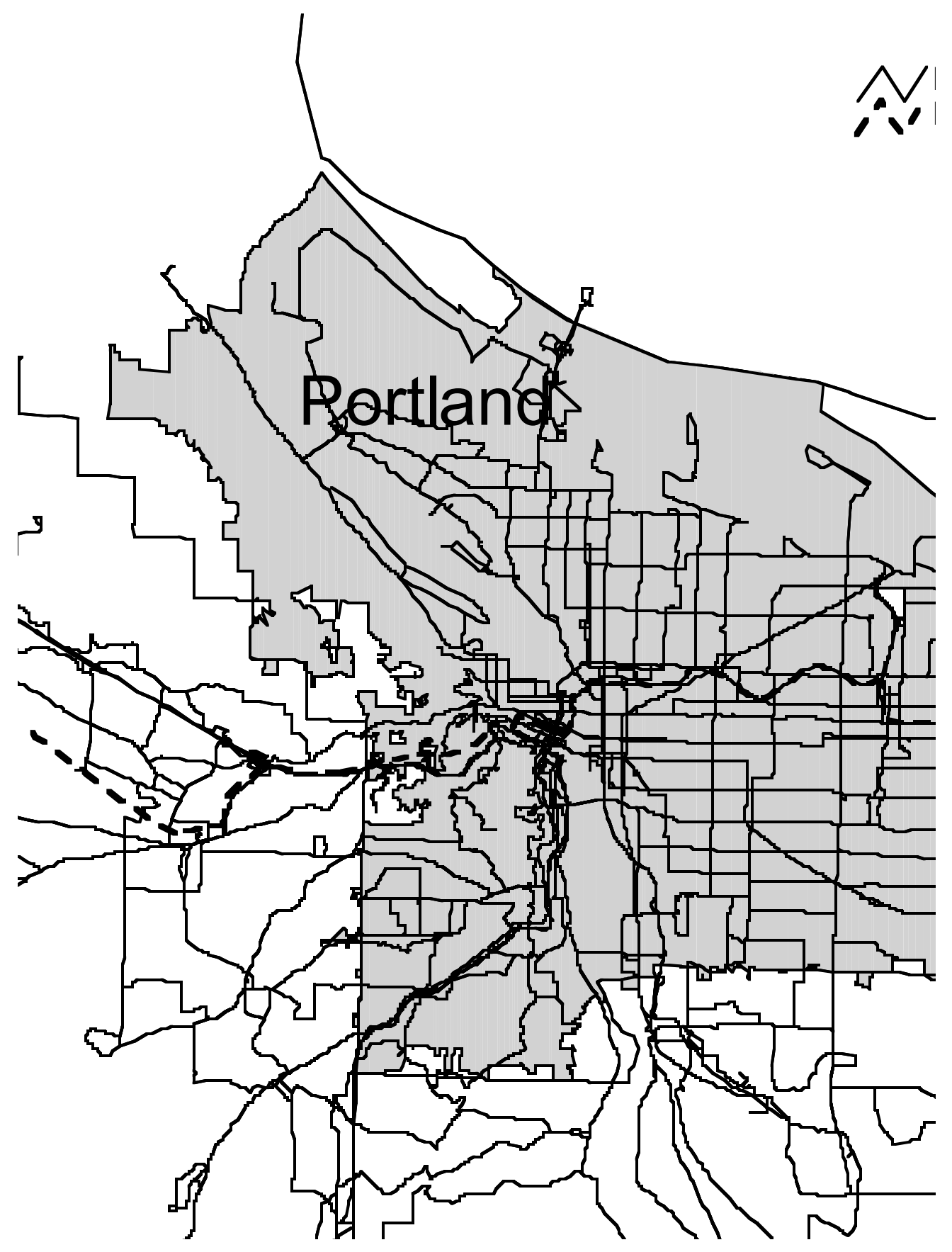


Figure 2 City of Atlanta

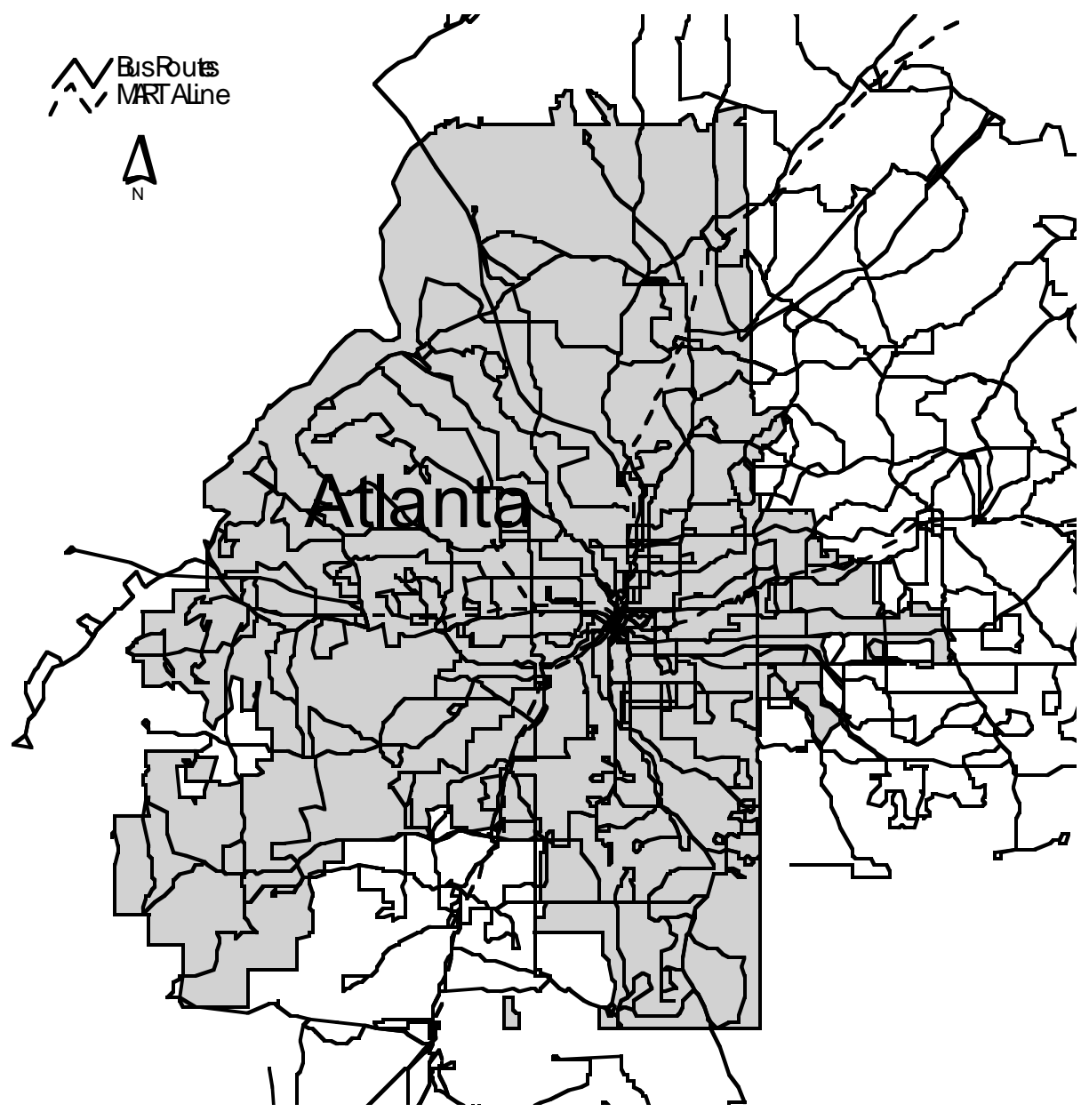


The other two spatial measures control for accessibility to certain job classes. It is argued that accessibility to service or retail related jobs is an important factor for low skill or underemployed workers. For both service and retail jobs (as defined by the census), an employment accessibility index was calculated for each block group. Each block group centroid was used as the origin with TAZ centroids containing the numbers of service and retail jobs as destinations. Accessibility was calculated using the bus route network with a search radius constrained to an average 25 minute travel time. The accessibility calculation was performed using the following equation:

where:

$$
\mathrm{P}_{i}=\sum_{j=1}^{n} \mathrm{~W}_{j} \mathrm{~d}_{i j}^{-\beta}
$$

$$
\begin{array}{ll}
\mathrm{P}_{i} & \text { is the accessibility of block group } i \\
\mathrm{~W}_{j} & \text { is the number of jobs in TAZ } j \\
\mathrm{~d}_{i j} & \text { is the travel time between } i \text { and } j \\
n & \text { is the exponent for distance decay } \\
n & \text { is the number of TAZs in each city }
\end{array}
$$

Indices for service and retail employment accessibility were estimated separately for each block group. The block groups with the highest accessibility measures are those that have good transit access to employment concentrations.

Two-stage least squares regression was used because of the potential interaction between the vehicle ownership variable and the level of labor participation for each block group. Employed persons can more easily afford a car than can unemployed persons. To avoid biased estimates because of the interaction between vehicle ownership and employment levels, per capita vehicle ownership was estimated in the first stage. Block group vehicle ownership rates were considered to be a function of average household sizes, average household incomes, average weeks worked annually, and distance from the urban core. The predicted values for car-ownership were then used in the second stage to predict average annual employment levels.

\section{$\underline{\text { Regression results }}$}

Regression equations that included the 13 independent variables were used to predict the average number weeks worked for all workers and also the average for nonwhite block groups in Portland and Atlanta (see Table 5). Seven block group variables were used as indicators of mobility and job access; average commuting time (comm_time), distance to the nearest rail stop (dist_rail), distance to the nearest bus route (dist_bus), frequency of transit service (frequent), service employment accessibility within 25 minutes (ser_jobs), retail employment accessibility within 25 minutes (ret_jobs), and the per capita number of vehicles (pre_veh). Five of the seven mobility and job accessibility variables were significant in predicting total employment participation for Portland, while only one was significant in predicting employment among nonwhites. The significant variable common to both the total and nonwhite equations was per capita vehicle ownership rates. The coefficients for vehicle ownership had similar magnitudes for both groups. For all block groups, average employment levels declined as the distance transit stops increased and average employment levels increased substantially as per capita vehicle availability increased. Relative transit access to retail or service job concentrations did not appear to have a significant impact on employment levels. It is interesting to note that access to bus and rail transit (stops) did not have significant relationships with employment levels for nonwhites while they did for all workers. This may be explained by the relatively uniform level of access that nonwhites have to transit.

Other significant variables in predicting total employment levels were educational attainment (pbach), presence of nonwhite youths (pnw_15), proportion of single parent households with children (psingwc), and racial composition (pwhite). In general, these same variables were significant 
in predicting nonwhite employment levels. Educational attainment (percent of workers with bachelors degrees) had an unanticipated negative sign while all other signs for significant coefficients were reasonable.

Table 5 Regression results 1

\begin{tabular}{|c|c|c|c|c|}
\hline & \multicolumn{2}{|c|}{ Portland } & \multicolumn{2}{|c|}{ Atlanta } \\
\hline Variable & Total & Nonwhite & Total & Nonwhite \\
\hline comm_time & $0.154 * *$ & 0.054 & $0.224 * *$ & $0.187 * *$ \\
\hline dist_rail & $-0.089 * *$ & -0.081 & $-0.573 * *$ & $-0.932 * *$ \\
\hline dist_bus & $-1.502 *$ & 0.147 & $-6.234 * *$ & $-3.847 *$ \\
\hline frequent & $-0.035 * *$ & -0.040 & -0.003 & -0.009 \\
\hline pbach & $-3.858 * *$ & -1.911 & $-4.520 *$ & 1.163 \\
\hline pexec & 2.429 & $7.084 *$ & 5.613 & 2.999 \\
\hline pleav_4 & 2.725 & 5.304 & 4.780 & 0.321 \\
\hline pnw_15 & $26.148 * *$ & $34.985 * *$ & $21.173 * *$ & $16.652 * *$ \\
\hline ret_jobs & 0.295 & 0.301 & $-2.467 * *$ & $-1.414 *$ \\
\hline ser_jobs & -0.271 & -0.392 & $2.082 * *$ & $1.418 *$ \\
\hline psingwc & $-12.477 * *$ & $-16.367 * *$ & $-13.934 * *$ & -3.787 \\
\hline pwhite & $4.556^{* *}$ & $7.501 * *$ & $3.790 * *$ & 2.639 \\
\hline pre_veh & $30.425 * *$ & $30.985^{* *}$ & $30.026 * *$ & $54.020 * *$ \\
\hline (Constant) & $20.059 * *$ & $19.146 * *$ & $23.157 * *$ & $12.833 * *$ \\
\hline $\mathrm{N}$ & 570 & 198 & 409 & 253 \\
\hline Adj R2 & 0.614 & 0.756 & 0.553 & 0.773 \\
\hline $\mathrm{F}$ & 70.510 & 47.931 & 39.759 & 67.015 \\
\hline Signif F & $<0.0005$ & $<0.0005$ & $<0.0005$ & $<0.0005$ \\
\hline
\end{tabular}

1 Dependent variables are average weeks worked for total and nonwhite block groups *significant at $\mathrm{p}<0.05, * *$ significant at $\mathrm{p}<0.01$

For Atlanta, all of the mobility and job access coefficients were statistically significant except for transit service frequency. In particular, the coefficients for bus transit access suggest that there is a strong association between proximity to bus stops and employment levels. For all block groups, the number of average annual weeks worked declined by approximately 3 weeks for every $0.5 \mathrm{~km}$ away from the nearest stop. For the nonwhite block groups the average weeks worked declined by approximately 1.9 weeks per $0.5 \mathrm{~km}$. Although statistically significant, the access to rail stops did not have as large an impact on employment levels as bus transit accessibility. In terms of other characteristics, the percent nonwhite youths was the only consistently significant block group variable. Based on evidence from the literature, the concentration of nonwhite youths was also expected to be associated with areas of lower labor participation levels - but it was not. One possible explanation for this result is that youths under 16 years of age do not typically work and rely upon the economic resources generated by their parents.

The remaining three variables; the ratio of bachelors degrees to number of workers (pbach), percent of workers in executive and managerial positions (pexec), and percent of workers leaving for work between 4:00 p.m. and midnight (pleav_4) were used as indicators of worker skill levels. As expected, the variables for the percent of executives and college educated persons were highly correlated (Portland: $r=0.673$, Atlanta $r=0.676$ ). It was anticipated that the proportion of persons working late shifts would be an indicator of low-wage, temporary, or low-skilled positions and be associated with higher levels of potential unemployment. The regression results did not suggest that this was the case for either Portland or Atlanta. 
In general terms, mobility and job accessibility factors had a larger impact on average employment levels for Atlanta block groups compared to Portland block groups. These differences may be more attributable to the demographic differences between the two cities than to differences in transit service levels. Although the rail transit coefficients were generally significant in predicting total and nonwhite annual labor participation for Portland and Atlanta, the coefficients only ranged from -0.080 to -0.932 . This means that workers living further from rail stops work only slightly less per year than workers living closer to rail stops. For Portland and Atlanta, the difference in average weeks worked for a worker within walking distance of a rail stop and a worker not within walking distance is less than 1 week per year. For Portland the difference is less than 1 day per year and for Atlanta it is only about 3 to 5 days per year. The bus transit access measure was significant in all but the nonwhite Portland block group equations. The difference in average weeks worked between workers within walking distance of a bus stop and workers not within walking distance was between 1 and 3 weeks per year (see Figures 3 and 4). It would seem that if transit were not providing a significant mobility benefit to workers that these differences would be more in the range of days worked per year rather than weeks.

Figure 3 Distance to bus transit and employment levels

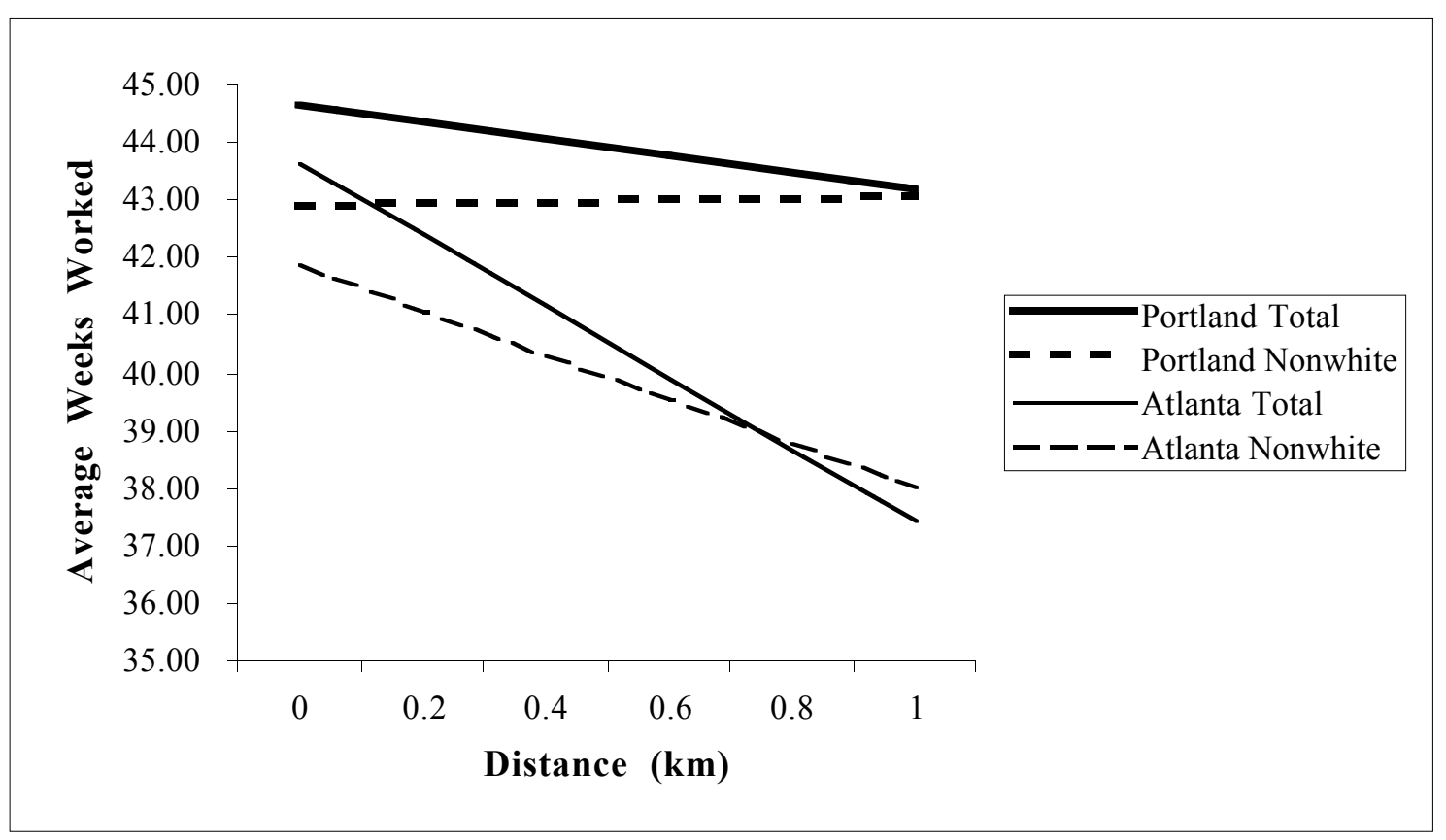


Figure 4 Distance to rail transit and employment levels

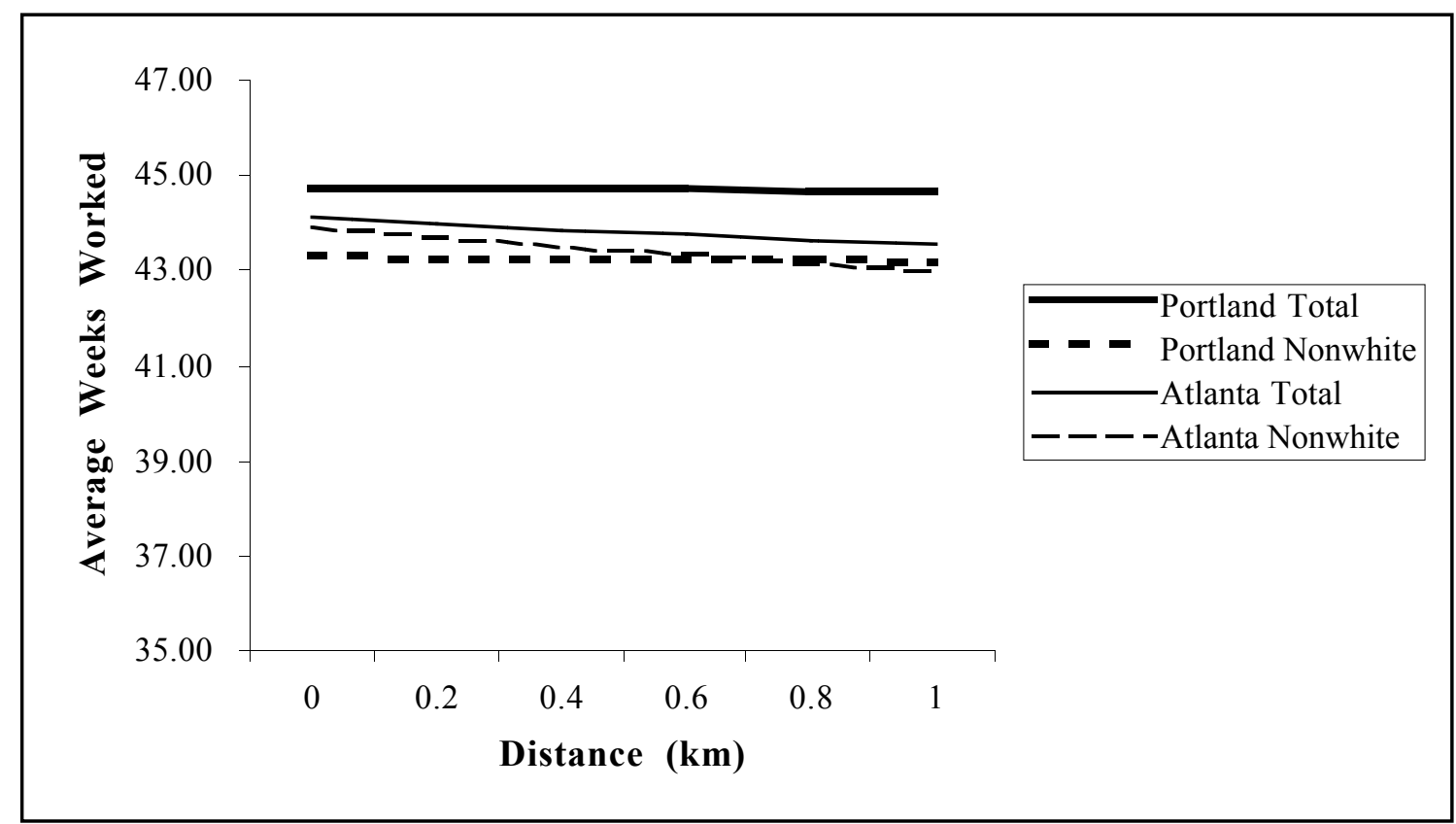

The likelihood of multicollinearity increases whenever multiple spatial and transportation accessibility measures are included within a single regression equation. In this case three measures (bus access, rail access, and commute time) are potentially correlated and could be biasing the regression results shown in table 5. As might be expected, the rail and bus access measures were positively correlated for Portland and Atlanta. However, the simple correlation coefficients were not considered to indicate serious multicollinearity with coefficients below 0.40 . In addition, correlation coefficients between variables for average commuting time, rail access, and bus access were all below 0.20 and not considered to represent serious levels of multicollinearity (see table 6).

Table 6 Correlation matrix for transportation accessibility measures

\begin{tabular}{lccc}
\hline Portland & $\begin{array}{c}\text { Commute } \\
\text { Time }\end{array}$ & $\begin{array}{c}\text { Rail } \\
\text { Access }\end{array}$ & $\begin{array}{c}\text { Bus } \\
\text { Access }\end{array}$ \\
\hline Commute Time & -- & 0.096 & 0.153 \\
Rail Access & 0.096 & -- & 0.371 \\
Bus Access & 0.153 & 0.371 & -- \\
Atlanta & & & \\
Commute Time & -- & 0.072 & -0.160 \\
Rail Access & 0.072 & -- & 0.392 \\
Bus Access & -0.160 & 0.392 & -- \\
\hline
\end{tabular}

The model performed reasonably well and explained approximately 55 and 61 percent of the variation in total employment participation among workers. The model performed better for predominantly nonwhite block groups, predicting approximately 77 percent of block group variation. Controlling for neighborhood and household characteristics, job skills, levels, and job 
proximity factors, the analysis suggests that in general, transit access is potentially correlated with employment participation levels in Portland and Atlanta. The impact of bus transit access appears to be more substantial than that for rail access.

\section{$\underline{\text { Conclusion }}$}

Based on the results of this analysis, policies advocating increased transit accessibility in addressing urban underemployment are partially supported. Of the previous research that has been performed in this area, none has empirically addressed the claim that public transportation represents an effective or efficient strategy to combat unemployment. Despite other findings in the spatial mismatch literature, it appears possible that transit can overcome the physical separation between the residential locations of nonwhite workers and job locations. When nonwhite workers have reasonable access to employment concentrations and remain underemployed, employer discrimination, inadequate education, and insufficient job training are often cited as contributing factors. Proposals for long-term strategies for increased job training, job information, transportation enhancements, day-care services, tax credits, and policing and correctional practices (see Hughes 1991) avoid the underlying theme of spatial mismatch -- racial discrimination. If discriminatory practices in land use or employment activities are the fundamental problem, none of these strategies are appropriate. If discrimination is truly the problem, the most direct response appears to be stricter enforcement of civil rights legislation (Kasarda 1983).

Certainly the study results cannot indicate a causal relationship between increased transit access and labor participation. Because residential location decisions are commonly influenced by factors related to transit accessibility, the role of transit in obtaining or maintaining employment is not discernable from this analysis. It may be the case that workers with low levels of mobility choose residential locations near transit to address personal mobility problems. On the other hand, it is also possible that as unemployed persons find work and increase their financial resources, they will likely purchase a vehicle. Work for these persons may translate into an increased level of automobile availability and act as a disincentive to use transit. For this reason, the positive relationship between transit accessibility and labor force attachment may not be coincidental.

Why then might employment levels not be positively influenced by the availability of transit service? First, poor route configuration could mean that although a worker has good access from her or his place of residence, the transit system may not go close enough to appropriate employment locations (destinations) (Meyer and Gómez-Ibáñez 1981). Second, transit may provide an insufficient level of service (frequency, coverage, etc.) at off-hours for entry-level, low-skill, temporary, or shift-work positions (Kihl, Knox, and Sanchez 1997). Although transit services are available when workers leave for work, service may be unavailable when they need to return home, therefore providing inadequate round-trip service. Third, transit may simply not be seen as a costeffective means of transportation to work. This may be a function of the lack of knowledge about transit routes and scheduling or the unwillingness of workers to trade off the time cost of travel by bus for its lower overall travel costs compared to autos (O'Sullivan 1993). It would seem, however, that if a lack of mobility or employment accessibility contributes to low labor participation rates, transit would at least provide a solution for a portion of low-income workers. The data analyzed in this study support this hypothesis.

If employer discrimination is a secondary factor in the pattern of urban employment, perhaps interventions for the issues mentioned above are appropriate policy responses. This analysis focuses on one of the strategies commonly recommended, using public transportation to address underemployment. While the results of this analysis present an optimistic outlook on the transportation solution, to conclude that public transportation can in itself overcome the job accessibility and mobility problems of urban workers is premature. The results of this analysis also support the findings of previous research on the spatial mismatch hypothesis - that vehicle ownership remains a key factor in job accessibility and labor participation.

Considering the challenges routinely faced by transit operators in providing efficient service amidst increasing automobile dependency, dispersed and transit inaccessible land use patterns, it 
becomes clear that transit's role in employment based transportation is changing and becoming more difficult. Serving dense central city employment patterns carried with it inherent efficiencies that made transit a more competitive mode in terms of cost and convenience. The transit industry has been confronted by the need to sustain a minimum level of service to central cities, while employment has decentralized and become a moving target (CTAA 1998). Thus transit agencies have faced reduced ridership and revenue amidst simultaneous demands for new service to dispersed employment in the suburbs that is inherently more costly to provide. Transit service also traditionally operates in a political environment where reducing service in one place to increase it elsewhere is resisted by governing boards. If urban service is less utilized than it once was, but is still desired by remaining transit customers, it is difficult to sustain political arguments to provide new services in the suburbs where the current demand is smaller or latent and the automobile is the focus of land use site design.

The Welfare to Work challenge highlights the emerging reality that the automobile-based economy and traditional urban transit has not adequately provided opportunity to the urban and rural poor, who, without automobiles, can not easily participate. Welfare Reform and the Transportation Equity Act for the 21st Century (TEA-21) have recognized this and are providing additional funding for transit and mobility services. But absent new efficiencies and innovation, these funds will not be sufficient to institute comprehensive employment based transportation on top of existing transit services. In addition, additional research is needed to better understand the dynamics between transportation mobility needs and employment activities. Much emphasis has been placed on the transportation needs of persons obtaining new jobs, while still little is known about issues related to job retention. 


\section{$\underline{\text { References }}$}

Altshuler, Alan A. 1966. Transit Subsidies: By Whom, For Whom? Journal of the American Institute of Planning, 35: 84-89.

Aponte, Robert. 1996. Urban Employment and the Mismatch Dilemma: Accounting for the Immigration Exception. Social Problems, 43: 268-283.

Blackley, Paul R. 1990. Spatial Mismatch in Urban Labor Markets: Evidence from Large U.S. Metropolitan Areas. Social Science Quarterly, 71: 39-52.

Bullard, Robert D. 1996. Introduction: Environmental Justice and Transportation. Environmental Justice and Transportation: Building Model Partnerships: Proceedings Document, Clark Atlanta University.

Bullard, Robert D. and Glenn S. Johnson, Eds. 1997. Just Transportation: Dismantling Race \& Class Barriers to Mobility. Gabriola Island, BC: New Society Publishers.

Cohn, Samuel and Mark Fossett. 1996. What Spatial Mismatch? The Proximity of Blacks to Employment in Boston and Houston. Social Forces, 75: 557-572.

Community Transportation Association of America. 1998. Access to Jobs: A Guide to Innovative Practices in Welfare-to-Work Transportation. Washington, D.C., CTAA.

Dajani, Jarir S. and Michael Egan. 1974. Income Distribution Effects of the Atlanta Transit System. Transportation Research Record, 516: 35-46.

Downs, Anthony. 1992. Stuck in Traffic. Washington: The Brookings Institution.

Ellwood, David T. 1986. The Spatial Mismatch Hypothesis: Are There Teen-Age Jobs Missing in the Ghetto? In The Black Youth Employment Crisis, edited by Richard B. Freeman and Harry J. Holzer. Chicago: University of Chicago Press.

Environmental Justice Resource Center. 1996. Environmental Justice and Transportation: Building Model Partnerships: Proceedings Document, Clark Atlanta University.

Frankena, Mark. 1973. Income Distributional Effects of Urban Transit Subsidies. Journal of Transport Economics and Policy, 215-230.

Gómez-Ibáñez, José A. 1976. Assessing the Arguments for Urban Transit Operating Subsidies. Transportation Research Record, 573: 126-132.

Gordon, Peter, Ajay Kumar and Harry W. Richardson. 1989. The Spatial Mismatch Hypothesis: Some New Evidence. Urban Studies, 26: 315-326.

Hendrickson, Chris. 1986. A Note on Trends in Transit Commuting in the United States Relating to Employment in the Central Business District. Transportation Research-A, 20A: 33-37.

Hernandez, Martin. 1996. Public Transit in Los Angeles. Environmental Justice and Transportation: Building Model Partnerships: Proceedings Document, Clark Atlanta University.

Hodge, David C. 1995. My Fair Share: Equity Issues in Urban Transportation, In The Geography of Urban Transportation, edited by Susan Hanson. New York: The Guilford Press.

Holloway, Steven R. 1996. Job Accessibility and Male Teenage Employment, 1980-1990: The Declining Significance of Space? Professional Geographer, 48: 445-458. 
Holzer, Harry J. 1991. The Spatial Mismatch Hypothesis: What Has the Evidence Shown? Urban Studies, 28: 105-122.

Holzer, Harry J., Keith R. Ihlanfeldt, and David L. Sjoquist. 1994. Work, Search, and Travel Among White and Black Youth. Journal of Urban Economics, 35: 320-345.

Hughes, Mark Alan. 1991. Employment Decentralization and Accessibility: A Strategy for Stimulating Regional Mobility. Journal of the American Planning Association, 57: 288-298.

Ihlanfeldt, Keith R. 1994. The Spatial Mismatch Between Jobs and Residential Locations Within Urban Areas. Cityscape, 1: 219-244.

Ihlanfeldt, Keith R. and David L. Sjoquist. 1990. Job Accessibility and Racial Differences in Youth Employment Rates. The American Economic Review, 80: 267-276.

Kain, John F. 1968. Housing Segregation, Negro Employment, and Metropolitan Decentralization. Quarterly Journal of Economics, 82: 175-197.

Kain, John F. 1992. The Spatial Mismatch Hypothesis: Three Decades Later. Housing Policy Debate, 3: $371-460$.

Kain, John F. and John R. Meyer. 1970. Transportation and Poverty. The Public Interest, 18: 75-87.

Kasarda, John D. 1983. Entry-Level Jobs, Mobility, and Urban Minority Unemployment. Urban Affairs Quarterly, 19: 21-40.

Kihl, Mary, Jerry Knox, Thomas Sanchez. 1997. Alternative Approaches to Providing Passenger Transportation in Low Density Cities. Final Report. Iowa State University, Iowa Department of Transportation.

Levinson, David M. and Ajay Kumar. 1994. The Rational Locator: Why Travel Times Have Remained Stable. Journal of the American Planning Association 60,3: 319-332.

Meyer, John R. and José A. Gómez-Ibáñez. 1981. Autos, Transit, and Cities. Cambridge: Harvard University Press.

Murakami, Elaine and Jennifer Young. 1997. Daily Travel by persons with Low Income. Paper presented at the NPTS Symposium, Bethesda, Maryland.

National Advisory Commission on Civil Disorders. 1968. Report of the National Advisory Commission on Civil Disorders. Washington: U.S. Government Printing Office.

Offner, Paul and Daniel H. Saks. 1971. A Note on John Kain's 'Housing Segregation, Negro Employment and Metropolitan Decentralization.' Quarterly Journal of Economics 191: 147160.

O’Sullivan, Arthur. 1993. Urban Economics. Homewood, Il.: Irwin.

Sanchez, Thomas W. 1998. Equity Analysis of Personal Transportation System Benefits. Journal of Urban Affairs 20,1: 69-86.

Taylor, Brian D. and Paul M. Ong. 1995. Spatial Mismatch or Automobile Mismatch? An Examination of Race, Residence, and Commuting in U.S. Metropolitan Areas. Urban Studies, 32: $1453-1473$.

Thompson, Gregory L. 1997. How Ethnic/Racial Groups Value Transit Accessibility: Modeling Inferences from Dade County. Paper presented at the Annual Meeting of the American Collegiate Schools of Planning, Ft. Lauderdale, Florida. 
UMTA. 1979. Analyzing Transit Options for Small Urban Communities - Analysis Methods. Washington: U.S. Department of Transportation.

U.S. Bureau of the Census. 1992. 1990 Census of Population and Housing, Summary Tape File 3 on CD-ROM: Oregon. Washington, D.C.

U.S. Department of Transportation, Bureau of Transportation Statistics. 1998. Welfare Reform and Access to Jobs in Boston, BTS-98-A-02, prepared by Annalynn Lacombe, Washington, DC.

Wachs, Martin and Brian D. Taylor. 1998. Can Transportation Strategies Help Meet the Welfare Challenge? Journal of the American Planning Association, 64, 1: 15-19.

Washington, James M., Ed. 1986. A Testament of Hope. San Francisco: Harper Collins.

Willis, Nancy. 1997. Welfare to Work: Where Community and Transportation Advocates Meet. Progress. Surface Transportation Policy Project, VII (8): 5-6.

Wilson, William Julius. 1997. When Work Disappears. Political Science Quarterly, 111: 567-595.

Wilson, William Julius. 1987. The Truly Disadvantaged: The Inner City, the Underclass, and Public Policy. Chicago: University of Chicago Press.

Wyly, Elvin K. 1996. Race, Gender, and Spatial Segmentation in the Twin Cities. Professional Geographer, 48: 431-444. 